\title{
Fanning the flames of non-conformity
}

\section{James Derounian}

University of Gloucestershire, UK

\section{Abstract}

This opinion piece argues that higher education is, and should be, about the systematic encouragement of independent thought, action and non-conformity, but that various forces act against these intentions. The author issues a rallying cry for the re-ignition of the flames of non-conformity... as a contribution to the future wellbeing of higher education.

Keywords: non-conformity; academic assertiveness; independent thought; co-production of learning.

\section{Introduction}

Higher education, according to the Quality Assurance Agency for Higher Education (QAA) should 'place learning at the heart of University practice - learning about, with and from students' (Kay et al., 2010, p.9). But the author contends that this aspiration often falls short and mutates in to impoverished learning for students.

In this short article I want to argue for the conscious and deliberate promotion of student non-conformity in their learning. My arguments are supported by academics and practitioners. For example the late, great, Martin Luther King Jnr argued as far back as 1963 that this 'hour in history needs a dedicated circle of transformed nonconformists... The saving of our world from pending doom will come, not through the complacent adjustment of the conforming majority, but through the creative maladjustment of a nonconforming minority' (King, 1963, pp. 27-28). Without such questioning of the status quo we'd still believe that the Earth lies at the centre of the universe, and creationism, not Darwinism, would provide our worldview. 
Sally Feldman (2008, p.27), a Dean of Faculty at Westminster University puts the case eloquently 'in praise of derring-do. Of daredevils. Of mavericks and risk-takers and chancers and wild cards. Because to be dangerous and fearless goes hand in hand with genius and without it we're stuck...If there's one quality I hope our students will hang on to, it is courage in the face of wimpishness and cravenness'. The academic researcher Jenny Moon (2009, p.4) captures this dangerous but potentially constructive capability and argues that higher education should foster 'academic assertiveness'. She defines this as 'a set of emotional and psychological orientations and behaviours that enable a learner appropriately to manage the challenges to the self in the course of learning and their experiences in formal education and personal development work' (Moon, 2009, p.4). Assertiveness embraces facets such as finding an appropriate 'voice' through which to engage in debate and critical thinking; and a 'willingness to challenge, to disagree and to seek or accept a challenge' (Moon, 2007, p.6). This approach fits squarely with aspirations for university education that hones critical faculties, and certainly - in the social sciences with notions of contested ideas. From my own field of local governance, for example, there are disagreements, disputes and contradictory or diverging evidence in relation to the pros and cons of participatory (by the people for the people) as opposed to representative (elected politicians) democracy.

Postmodernists emphasise the plurality of truth - claiming that there is no truth absolute but a series of truths and valid perspectives. Postmodernism 'doesn't lament the idea of fragmentation, provisionality, or incoherence, but rather celebrates that' (Klages, 2003, online). Or put another way: the postmodernist's premise is 'that no definite terms, boundaries, or absolute truths exist'. So my contention is that by fostering individual students' non-conformity we, as teachers, are equipping them for life and work in a messy, disordered, rapid, ever-changing and complicated world. Ronald Barnett supports this approach. In his article 'Supercomplexity and the university' (1998, p.154) he argues that education must cause 'disturbance in the minds and in the being of students' in order to enable them to 'live at ease with this perplexing and unsettling environment' and help them 'make their own positive contributions to this supercomplex world'. He describes the educational mission as 'enabling individuals to act purposively in an environment where all bets are off, where everything is uncertain and where everything is challengeable' (Barnett, 2000, p.419). This perspective also leads in to the co-production of learning and knowledge, which is a joint responsibility and undertaking for student and lecturer. In terms 
of medical research Morris et al. (no date, p.8) explain this co-production of learning 'moving on through shared understanding'.

Clearly academics don't have all the answers! Or even know the questions to ask! Collaboration with our students may (initially) be uncomfortable and a sort of voyage without chart and compass, but it can harness the talents, knowledge and skills of both parties and thereby extend the light of understanding. Again, from my own field of community engagement, I have sought contributions from students already engaged in work with local authorities, projects, programmes, policy development and community regeneration. Why should I rehearse the arguments of a community development officer when there are several in the classroom or online who are better equipped to do the job? It's also a great opportunity to draw graduates back in to teaching first degree and postgraduate students. This offers another aspect of non-conformity - practitioner inputs to academic teaching via student placements, live projects, shadowing, guest lectures and field visits. In this way students can make sense of theory and practice, and synthesise differing perspectives to reach their own conclusions.

\section{Barriers...and opportunities}

So where are the obstacles to encouraging non-conformity and questioning in higher education? Well for a start there are (undergraduate) assignment briefs that may be highly prescriptive. Where the lecturer 'calls the shots' and (mixing my metaphors!) the student 'jumps through the hoops'. A way out of this may be to open out the assessment briefs: for example in one of my final year modules ('Contemporary Governance') students 'examine in detail two different perspectives on a contested issue affecting a specific local community of place or interest and relevant to community governance and/or sustainable communities. In other words you present a debate between at least two opposing parties' (Derounian, 2010, p.12). So students can select the topic, the location and the opposing factions to explore. Closed and open book exams will present a similar issue in terms of questions posed by the assessor that the student must engage with in order to pass.

Then there are concerns about curriculum coverage. If a course or module is delivered over say 12-15 weeks of a semester, then opportunities to diverge from the structure and content may undermine, or be viewed by staff (and recipients) to do so, the coherence or 
academic integrity of a course of study. One counter to this can be in the form of 'independent study' modules of all hues - including dissertations, projects, placements, consultancy reports and 'live project' scrutiny; plus tutorial and seminar discussions. The use of online communication, through Virtual Learning Environments (VLEs) like Moodle and Blackboard and more recently Web2.0 technologies can be used to foster 'out of the box' contributions - (in my experience) some students feel a lot happier setting down views online, than in person/face-to-face.

There may be staff concerns about loss of control, and uncertainty about where unexpected and challenging student contributions may lead. Similarly from students, there might be doubts about 'value for money' and suspicion that they are being asked to make up for lecturer deficiency of knowledge, with their own research, insights and contributions. Lecturers need to adapt to the idea of being first amongst equals as opposed to the expert and fount of all knowledge. There may also be subjects where questioning and nonconformity can be less appropriate than others...as a social scientist I simply don't know how appropriate my argument is to 'hard sciences' like medicine, mathematics and so on...but I do think that at least the attempt or thinking about the encouragement of questioning and blind conformity is worthwhile. This is something that JD Bernal, the Marxist philosopher of science, understood very well when he argued that the scientist should be citizen first and scientist second. Differing views and perspectives can be used as a basis for reflection - on what are we doing, why are we doing it, and how could it be improved?

\section{And finally...}

The furtherance of non-conformity also promotes self-reliance: as the Unitarian Wayne Arnason (cited Unitarian Universalist Association, 1993, \#698) has said, 'take courage friends. The way is often hard, the path is never clear, and the stakes are very high. Take courage. For deep down, there is another truth: you are not alone. I am not alone. We are not alone. And together, we are enough'. In similar vein Mahatma Gandhi challenges us to be active rather than passive citizens: 'Be the change you want to see in the World' (Potts, 2002). 


\section{Acknowledgement}

The author would like to acknowledge the comments received from his colleague, Martin Jenkins (University of Gloucestershire).

Potts, M. W. (2002) 'Arun Gandhi Shares the Mahatma's Message' India - West [San Leandro, California] Vol. XXVII, No. 13 p. A34

\section{References}

Barnett, R. (1998) 'Supercomplexity and the university', Social Epistemology: A Journal of Knowledge, Culture and Policy, 12(1), pp. 43-50.

Barnett, R. (2000) 'University knowledge in an age of supercomplexity', Higher Education, 40(4), pp. 409-422.

Derounian, J.G. (2010) Contemporary governance (module guide 2010-11). Cheltenham: University of Gloucestershire.

Feldman, S. (2008) 'Clear and present danger', THE Times Higher Education, 4 December, p.27 (Online). Available at: http://www.timeshighereducation.co.uk/story.asp?storyCode $=404598 \&$ sectioncode $=$ 26 (Accessed: 22 February 2011).

Kay, J., Dunne, E. and Hutchinson, J. (2010) Rethinking the values of higher education students as change agents? Gloucester: QAA. Available at: http://www.qaa.ac.uk/students/studentEngagement/StudentsChangeAgents.pdf (Accessed: 22 February 2011).

King, M.L. (1963) Strength to love. Philadelphia: Fortress Press.

Klages, M. (2003) Postmodernism. University of Colorado at Boulder. Available at: 
http://www.colorado.edu/English/courses/ENGL2012Klages/pomo.html (Accessed: 22 February 2011).

Moon, J. (2007) Critical thinking requires academic assertiveness. Bristol: Subject Centre for Education ESCalate. Available at: http://escalate.ac.uk/3726 (Accessed: 22 February 2011).

Moon, J. (2009) Making groups work: improving group work through academic assertiveness in higher education and professional development. Bristol: Subject Centre for Education ESCalate. Available at: http://escalate.ac.uk/downloads/5413.pdf (Accessed: 22 February 2011).

Morris, P., O’Neill, F., Armitage, A., Lane, R., Symons, J., Dalton, E., Gaines, M., Katz, A. and Reed, J. (no date) Moving from tokenism to co-production: implications of learning from patient and community voices in developing patient centred professionalism. Available at: http://www.cihm.leeds.ac.uk/new/wpcontent/uploads/2009/05/Penny Morris.pdf (Accessed: 22 February 2011).

Potts, M. W. (2002) 'Arun Gandhi Shares the Mahatma's Message' India - West [San Leandro, California] Vol. XXVII, No. 13 p. A34.

Unitarian Universalist Association (1993) Singing the living tradition: \#698. North America: Unitarian Universalist Association.

\section{Author details}

James Derounian is Principal Lecturer in Community Development and Local Governance, and a National Teaching Fellow, at the University of Gloucestershire in the Department of Natural and Social Sciences. 